\title{
A Summary of the Developments Regarding the Economic Regime Implemented in Developed and Developing Countries
}

\author{
Asst. Prof. Dr. Özlen Hiç Birol (Istanbul University, Turkey)
}

\begin{abstract}
Since the developments regarding the economic regime in developed countries follow a different path as opposed to those in developing countries, in this article, these two groups of countries will be examined separately. Priority will be given to investigating the economic regime in developed countries due to historical and theoretical reasons. Today, both in developed and developing countries the economic activities basically are taken up by the private sector; nevertheless the government contributes to these activities through intervention, guidance, protectionism, and investment. Still the level of government intervention, protection and public investments in developed countries appears to be at the minimum. The role of government in developing countries, on the other hand, seems to be more significant; the gravity of the government's role depends on the degree of development for the countries concerned. In the countries where the level of development is low, the role of government increases, that is to say, the improvement in development decreases the role government.
\end{abstract}

\section{Outlines of the Economic Regime}

What is meant by the economic regime or the economic system is to identify whether fundamental economic and social activities such as production, allocation of resources, and distribution of income are conducted by the government or the private sector and to what extent. One of the major subjects of the economic regime has to do with the issues of foreign trade and economic relations, and the existence of market economy or government restrictions and protectionism.

As it is well understood by the definition given above, there are two extremes in this topic. First one requires that all economic and social activities are conducted by the private sector through price and market mechanism and profit maximization principle based on the free interaction. In this economic regime, private ownership is essential. Considering their own interests, the owners of land and capital decide which goods to produce and how much to produce, which type of technologies they will use, and how much labor they will employ according to the market conditions, supply and demand, and prices and wages. It is claimed that in the end, the optimal point, in other words, full employment equilibrium and at the same time, balance of payments are reached automatically. Under these circumstances, the government should only carry on its classical functions such as external and internal security, the judiciary and health and education. Although this economic regime, first introduced in the 18th century, is called the "liberal economic regime" as a result of the inspiration from the Marxist publications, it has come to be named as "capitalism".

The second extreme or the opposite end of the spectrum would refer to all economic and social activities that are carried out by government. K. Marx and Marxists call this economic system as "socialism"; but the term generally used and accepted is "communism". In the communist system, the ownership of the land and capital which are the main factors of production is in the hands of the government. The government conducts all economic and social activities by means of central planning.

At this stage, it is necessary to touch upon the interaction between these different economic regimes with the political regime. The political regime which is commensurate with the liberal economic regime seems to be democracy which upholds individual freedoms up to the maximum level. Although in autocracies, private sector also plays an important role in economic activities as it was the case with Hitler and Nationalist Socialism, Mussolini and Fascism, the private sector has to be compliant with government's restraints and directions. Similarly, in the countries where democratic regime is not fully implemented, there again private sector is subjected to various pressures coming from the government. On the other hand, the communist regime essentially emerged as a dictatorship regime; government ownership and central planning hence government conducting all economic and social activities cannot exist side by side with any multi-party system or true "democratic" political system.

At the very outset it should be stated that, these two extreme regimes are not practically enforced. The implementation of private sector conducting all economic activities had begun in the developed countries, yet since they had caused various problems government started to take part in many economic and social activities by means of macroeconomic and social interventions, and government aids. At present this economic regime is identified as "mixed economy" in many standard economics books; here the main point is to emphasize the existence of both the private and the public sector together. Still the term of "mixed economy" would not give away the fact whether the role of government or private enterprise is more important, and it can sometimes even be misleading. That is why both international economic institutions and economics literature mostly make use of the term of "market economy". 
The alternative to it as a second extreme or the opposite end of the spectrum which is government conducting all activities disappeared in practice since the collapse of the Union Of Soviet Socialist Republics (the USSR) and China's transformation into a mixed economy with private enterprise. All these developments will be dealt more thoroughly in the following sections.

\section{Evolution of the Economic Regime in the Developed Countries}

\subsection{The Birth of Liberal Economic Regime}

Before the advent of the science of economics, throughout the $16^{\text {th }}-18^{\text {th }}$ centuries, European countries, in other words, the developed countries at that time, implemented a very heavy interventionist and protectionist economic regime which was dubbed by Adam Smith as "Mercantilism". In Mercantilism each county was cutting down on its imports as much as possible whereas promoting its exports. But these countries could not issue the gold which was entering the country as the result of their foreign trade surpluses into the market as money; the gold was accumulating in the vaults of the Central Bank. The countries believed that this was the only way their countries' wealth would increase. Eventually, Mercantilism was restraining the volume of foreign trade among developed countries on one hand, and on the other hand it was reducing their rate of growth. Additionally, Mercantilism led these countries to colonialism (imperialism). The rational behind possessing a colony was to have cheap raw material and to be able to sell their goods at high prices.

However, the "industrial revolution" brought about significant changes in these countries. With the invention of steam engine, boat and train transportation expanded to a great extent, factories emerged as a result of mechanization of the weaving looms. According to Arnold Toynbee, the industrial revolution evolved through 1760-1840; first started in England and then it spread throughout other European countries. The industrial revolution created rather a large group of entrepreneurs. The most significant of all is the fact that these entrepreneurs started to realize that heavy interventionism and protectionism of the government, in fact, were restraining their economic activities and decreasing their profits. In his work written in 1776, Adam Smith identified this important development; when he was establishing the science of economics, he claimed that through the liberal economic system he developed, the government taking off his hands from all the economic activities would result in the most optimal economic and social outcome for the whole society. Adam Smith assumes that in all markets including the labor market, perfect competition prevails. In an economy under these conditions, the "invisible hand", that is the price mechanism, will solve all economic problems at an optimum point for the whole society. Full employment equilibrium will be reached automatically, and the balance of payments will restore itself so that the trade balance will be reached automatically via the automatic gold standard theorem (Hiç, 1994). In this case, any intervention or protection coming from government would disrupt the equilibrium, and the welfare of the society would decrease. In perfectly competitive markets, the profits of the firms would fall down to their "normal" levels under. However, if monopolies arise, the government should abolish the monopoly. The government should not intervene on wages. However, if labor union (labor monopoly) emerges, the government should intervene again; as the monopolist wage rises of the unions would prevent the economy from reaching the full employment equilibrium automatically.

Free foreign trade based on Adam Smith's absolute advantage theory has gained validity and universality through David Ricardo's (1817) comparative advantage theory; this theory is still valid in our times.

The classical model based on Adam Smith the following classical economists developed further by Alfred Marshall in 1890. For detailed information about the economic model mentioned in the macroeconomic literature as the classical system or the simple classical system (not containing the Keynesian self-correcting features), one can refer to macro economy books such as Hiç (1994), Paya (1997), Ackley (1961), Branson (1989). In this article, though, there is no need to go into the details of the classical system, as for a collective information about classical economists, please refer to Hiç (1974, ps. 1-9)

We can safely assume Adam Smith as the starting point of the science of economics and the implementation of economic policies based on this science. As mentioned before, Smith's system is called "liberal economic regime" or laissez-faire. The very same economic regime had been named by Marx and Marxist writers as "capitalism" or "wild capitalism".

In practice, the implementation of "Laissez-faire" has caused two main problems. Firstly, through its implementation in the early years, the conditions of the workers got worsened, that is the "labor problem" or "social problem". Secondly, economies did not grow at the full employment equilibrium. On the contrary, there had been continuous cyclical fluctuations, and the problem of unemployment in the depression period remained unsolved

\subsection{The Birth of the Communist System}

In 1848, Karl Marx, with F.G. Engels introduced the second extreme regime with their work the "Communist Manifesto" during the first period these serious labor problem and cyclical fluctuations, depression and unemployment encountered by the European countries. Marx, later on, developed his thoughts in Das Kapital (Vol. 1: 1867, Vol. 2: 1885, Vol. 3: 1884 after his death). 
According to Marx, the capitalist system was dynamic but it would give rise to exploitation of workers, monopolies and increased poverty of the workers; the business cycles stem from the nature of the capitalist system, and they are inevitable. Marx argued that the governments in the capitalist system had become the powns (true owners) of the capitalists and could not prevent this doom; on the contrary, the problem will become more serious. In fact, he derided all efforts such as establishing a social security system or wage-legislation. Marx also argued against the religion thought that the religion was there only to calm down and make the workers accept their poor plight.

Marx prophesized that the capitalist system would eventually be destroyed after a severe depression by a "bloody" revolution of workers who had nothing to lose but their chains. After capitalism is destroyed, Marx noted that the production of factors would be owned by the government or the community, free enterprise system would stop and the government would take up all economic activities including investment and production and would implement central planning. According to Marx, in such a system, exploitation of workers and business cycles would be eliminated, and we should have a prosperity, equality, true democracy and full-employment.

The Communist Manifesto had been adopted by all labor unions of the European countries, especially by the German labor unions. However the de facto developments had taken place very differently from Marx's arguments.

\subsection{De Facto Developments, Evolution of Laissez-Faire or Liberal System into the Market Economy}

Contrary to Marx's arguments, the governments of developed countries did not stay indifferent to problems of workers. Affected by the views of intellectuals on one hand and the voting potential of the workers in democracies on the other hand, as well as for humane reasons, almost all governments prioritized the issue of betterment of the conditions of the workers. In these early periods, the workers were given the fundamental rights such as prevention of child labor, limits of the working hours, provision of work safety by regulating working conditions, determination of the minimum wage. Even one more step further, the social security system was institutionalized and at the same time, the labor unions were granted the right to go on strike, the employer was given the right for lockout as opposed to the right to go on strike. By doing this, social objectives were first introduced in the liberal economic regime (laissez-faire) as public policy for the first time, meaning "rightist" standpoint heading towards "center-right". Thus, the conditions of the workers had started getting better.

The business cycles, however, could not be prevented until the Great Depression of 1929-1934. After the Great Depression, Keynes introduced his macroeconomic system through his work (1936) showing that the automatic full-employment equilibrium in the classical system was not a true assumption and that the economy will settle at a less-than-full-employment equilibrium if the government does not increase the level of aggregate demand. According to Keynes' macroeconomic system, in order to ensure the full-employment equilibrium and to prevent unemployment, the total expenditures should be increased up to the level which will bring about full employment; so the government would be implementing monetary policy (money, credit, interest rate) and fiscal policy (government expenditures, taxes). The central banks in charge of determining the amount of money and credit as well the interest rates, later on, have been made independent from governments; obviously, it is always possible for the central bank to consult with the government. The same macro policies would be implemented in the opposite direction to prevent inflationist periods. As for more detailed information about Keynes' macroeconomic system and monetary and fiscal policies, refer to Hiç (1994).

Keynes' ideas and policy recommendations were embraced by all European countries and implemented during the World War II (to decrease inflation) and after the war (to prevent the business cycles). The government interventions in the economy on a macro level (through monetary and fiscal policies) to avoid cyclical fluctuations and to ensure a full-employment has become and inseparable part of the economic regime.

After the Second World War II (1939-1945), the world had split into two parts as the Western World and the Communist Bloc. Since the European governments made again use of trade restrictions and protectionism before the World War I (1914-1915), in order to prevent this tendency, the liberalization of the free foreign trade was initialized through GATT (General Agreement on Tariffs and Trade) signed in 1947. The World Bank established in 1944 (with its first period name and function, IBRD: International Bank for Reconstruction and Development) as well and the IMF provided the implementation of the market economy in the Western World including the developing countries. Instead of liberal economy or laissez-faire, the economic regime comprising of social and Keynesian macroeconomic interventions has started to be called as "market economy".

In the 70s, stagflation aroused as a result of the increase in oil prices by the OPEC, consequently, conservatism in the general public in the US and in Europe increased, and the views against the Keynesian system, namely, Monetarism and Neo-Classical School became widespread. Nevertheless, the implementation of these policies (especially during R. Reagan in the United States through 1980-1988 and M. Thatcher in Britain through 19791988) did not bring about positive results, and on the contrary, unemployment increased. Upon this development, Keynesian macroeconomic system was inclined in the academic circles in the 80s. Alongside with the main Keynesian macroeconomic system, Post-Keynesian and New-Keynesian schools gained some momentum. The 
90s had seen the return to Keynesian macroeconomic policy implementations. As for more detailed information about these new macroeconomic schools, refer to Birol (2001).

The global financial crisis and recession started in September 2008 in the United States, and then spread to the whole world with serious dimensions (for details please refer to Hiç, 2010), resulted in very important outcomes in terms of macroeconomic policies and the market economy. Firstly, especially Reagan in the United States and Thatcher in Britain decreased the size of the government control over the financial sector, and this decrease in oversight was an important factor in the break out of the financial crisis. When the crisis arose, the financial sector was put under severe government control. Thus, the control of the financial sector was accepted as a requirement of the market economy. Secondly, alongside with the financial aid by government against the global crisis, intensive Keynesian macroeconomic policies such as decreasing the interest rates (monetary policy), changes in public investment programs and taxing system (fiscal policy) were implemented. Thus, the requirement for Keynesian macroeconomic policy implementation was confirmed. Thirdly, international cooperation was sought through G-20 instead of G-7, nevertheless though, in the essence, market economy and globalization process which started in the 90s were not abandoned (Hiç, 2010).

The fundamental element in market economy is the private sector; investment and production are delivered by private enterprise. Government, though, invests only in social and productive infra-structure fields; private investment is also allowed in these same areas. The sectoral and regional distribution of income is merely intervened on an exceptional basis. Government interventions are made on the grounds of Keynesian recommendations as well as for social objectives and they are limited only for those areas. Foreign trade is liberalized, restrictions on quotas are eliminated, and customs duties are at their minimum levels. The trade balance is reached by the exchange rates determined in foreign exchange market. Beside the free foreign trade, the entry of foreign private capital is also free. In the process of globalization, international flow of the financial funds plays the most significant role.

The market economy with its guidelines given above is being implemented in the freest fashion in the countries such as United States, Britain, Canada and Germany. On the other hand, in France, government control is traditionally and relatively more intense.

\subsection{Heading towards Social Democracy in Developed Countries}

Marx's Communist Manifesto of 1848 had been published by the German labor unions, and especially in Germany, labor unions in all European countries had embraced communism. Yet, the labor unions noticed the fact that, in time, the governments were dealing with social issues and progressively the conditions of workers were getting better. They also realized that they played an efficient role in these improvements, and eventually they moved away from communism and headed towards democratic socialism or, in short, towards socialism.

When the Marxist-Leninist communist revolution had broken out in Russia in 1917/1918, the majority of the labor unions in the European countries had left communism completely adopting democratic left movement. Only the minority groups had to be faithful to the communist system, and they had supported communist parties.

Following the communist revolution, the USSR had founded "Comintern" (an international association of communist parties) in 1919; however, this organization had been abolished in 1942. After the World War II, this time, the USSR established Cominform, and this organization, too, was disbanded in 1956.

After the World War II, the democratic leftist parties in Europe came together and founded the "Socialist International" in 1951. The Socialist International accepted democracy and market economy as a their principle. Within this framework, the promotion of democracy, human rights and equal opportunities were targeted and acknowledged. The Socialist International supported NATO, opposed the USSR and was pro-disarmament. The British Labor Party, the French Socialist Party and the German Democratic Party took part in the Socialist International as democratic leftist parties.

The developments in the field of social policy starting from the World War II up until today have improved relatively compared to the past. Those improvements including minority rights, women's rights, freedom of the media freedom of justice unemployment insurance health services and tax system taking into account the income distribution are among the fields where social democrats succeeded.

In relatively recent times, the democratic leftist parties headed towards the center-left. The British Labor Party and Tony Blair were the pioneers in this inclination. Today, the conditions of the workers in Europe and certainly in the United States have improved; many of them own their houses and cars, and they go to different countries on holiday.

The fundamental reason for the democracy functioning relatively well in the European countries seems to be the high level of education and the long standing democracy experience. As a result of this fact, the central-right and center-left (social democrat) parties share the majority of the votes whereas the liberals stand in between and in the middle. Both communist parties and anti-workers, racist, radical rightist parties are generally compose the minority. Moreover, the voters may vote differently depending on the time and conditions. This way, the centralleft presents a powerful alternative, and in many occasions, come into power and govern competently. The fact 
that the general principle of the both the central-right and the central-left happens to be democracy and the market economy plays an essential role in this outcome, because the difference between these two parties does not lie in the economic or political regime change, rather in their priorities and focus on the social targets. It should be kept in mind, however, that the economic growth and the employment as the social objectives are their common and most important targets they seek to accomplish.

\subsection{The Expansion and the Collapse of Communism}

According to Marx, to bring about a revolution by the working class and the establishment of socialism (communism) would only be happening in the "mature" industrialized countries; like in England and in Germany at his time. Yet, his expectation never materialized. Later on, the Marxist writers tried to explain this delay. For instance Rosa Luxemburg (1912) claimed that European countries turned to imperialism, and exploiting the colonies alleviated temporarily the exploitation of the workers; for a detailed information about Marxism and communism, refer to Hiç 1974, ps. 44-79.

Contrary to Marx's assumptions, in Tsarist Russia which was relatively less developed in terms of industrialization compared to the European countries at that time, in 1917 a minor militant group, but not the working class, staged a communist revolution taking advantage of the economic and political gap created by the World War II; and thus, Lenin established communism (bolshevism). The second wave of communism had been created, again not as a result of the revolution by the working class, but as an outcome of 1945 Yalta Conference attended by Churchill, Roosevelt and Stalin right after the World War II. In the conference, Northeastern and Balkan countries were left under the influence of the USSR, and eventually the USSR had brought communist dictatorship to these countries. The third important wave was China's becoming a communist country. After a long standing struggle with Chiang Kai-Shek and Japan, Mao Zedong founded People's Republic of China in 1949. Additionally, after serious internal and external problems and wars, North Korea, Cuba and two Indochina countries Vietnam and Laos had chosen the communist regime.

After the World War II, the USSR prioritized to bring communism to the developing countries as part of its expansionist policy, making use of her finances and propaganda towards this goal. Stalin, most probably, saw the fact that, virtually, there was no likelihood for the expansion of communism in the developed Western countries. Developing countries, though, were not yet industrialized, and many of them had a feudal structure. There were new departments established in universities to study and research on how these countries could become communist step by step. As a matter of fact, Şevket Süreyya Aydemir, the leader of cadre movement during Atatürk period, had studied this subject at Moscow University. This propaganda of the USSR, in general, had not been successful, and no country had chosen communism just because of such propagandas. On the other hand, the NEP (The New Economic Policy) implemented during Stalin era, based on the closed economy, importsubstitution, development strategy relying on public investments and central planning created an opinion that these elements were the reasons why the USSR achieved a very high growth rate; hence the NEP was taken as an example by many developing countries. Essentially, although the low level of development in these countries could not be compared to the one in the USSR, these countries generally required an economic regime featuring these strategies. Following this perspective, in India, even a Marxist model (Mahalanobis model) was put into practice; nevertheless, since it failed, in a year's time, it was abolished.

In time, it was realized that the central planning depending solely on public ownership and public enterprise brings about a restriction on the growth rate and technological progress, and public enterprise lacks the dynamism of that of the private enterprise. Eventually, the Soviet system, namely the communism, let alone to provide prosperity for the workers, it transformed into an oppression and police state. The communist regime caused setback to the development and industrialization of Russia and the countries part of the USSR states. The burden of the countries within the USSR on the Russian budget accompanied by the intensive military spending to compete with the United States incurred serious economic problems.

In the years when the communications facilities were limited, the Soviet propaganda was emphasizing freely that the conditions of the workers in Europe were very bad. However, in the following years, as the communications technologies have improved and the difficulty of restricting communications has become a reality, the people in Russia and in other member countries realized that the welfare of the working class in the European countries were much higher contrary what the propaganda was asserting; and that gave rise to discontent. In the end, let alone the claims of the USSR and Krushev to excel over the United States, even the glasnost efforts of Gorbachov did not prove fruitful. In 1990, the Berlin wall fell, and the East Germany broke its ties with Russia and acceded to the West Germany. In 1991 the USSR disintegrated and communism collapsed. Russia and all the now independent countries have chosen democracy and the market economy. Majority of the Northeastern European and Balkan countries have been accepted as a member of the EU (Karluk 2007). The others, though, have established the Commonwealth of Independent States with Russia, and all of them have forsaken communism. Both in Russia and in these countries, problems in the application of democracy and market economy pose a distinct challenge, yet none of them seem to be likely to return again to communism. 
With the collapse of the USSR, there are only five communist countries left in the world: China, Cuba, North Korea, Vietnam and Laos. However, a very significant development in China did occur though. After the death of Mao in 1976 and during the 80s, under the guidance of Deng Xiaoping, rather than following merely the doctrine, China opted for pragmatic economic policy. Being accepted as a member of the World Trade Organization in 2001, Chinese economic policy not only encouraged the private enterprise but started to encourage foreign private investment flow radically as well. At the same time, with this economic strategy based on the foreign private capital, China has occupied an important place in the globalization process of the $90 \mathrm{~s}$. Eventually, with its very high growth rate secured for a long time, in terms of the level of gross national product, she has reached the second position just right after the United States; but the per capita income level is still lagging behind. Today, what China implements as an economic regime is not a central planning which is peculiar to the communist system; the new regime which is open the external world could be considered as a mixed economy model based on encouragement of the private enterprise and private foreign capital. Thus, in practice, there are only four countries left that implement the actual central planning, and therefore they can be called communist countries: Cuba, North Korea, Vietnam and Laos. Cuba and Vietnam could leave communism if appropriate external and domestic opportunities arise, and eventually they may forsake the central planning in terms of economic regime, despite the fact that they may maintain their dictatorship structure. In short, from the point of the economic regime, communism and central planning which represent the second extreme have been dwarfed with no possibility of revival, getting close to the zero point. On the other hand, global economic and political problems are still handful, and new challenges are in the waiting.

\section{Evolution of the Economic Regime in the Developing Countries}

As to the problem of development and economic regime in the developing countries, this issue could be traced back to the aftermath of the World War II. The IMF and the World Bank set up after of the war had advocated the market economy as the economic regime for the developing countries in the Western world. Nevertheless, in the early stages of their development process, in the developing countries there were not enough private enterprises and private investment, and generally speaking, this led to very heavy interventionism, protectionism and public investment based, closed and import-substituted industrialization; the governments intervening the sectoral and regional distribution of income. In fact, the great majority of the economists and economic advisors of the developed countries during those years, actually advocated government interventionism and public investments due to lack of competitiveness in the markets of this countries and the existing price mechanism's not being a good indicator in terms of their productivity. Detailed information can be found in references of Hiç (2001), Toye (1993) and this paper.

As their development progressed, the intensity of the public investments, government interventions and protectionism has decreased gradually as a result of this development. Therefore, developing countries have proceeded in the opposite direction compared to the developed countries. Developed countries had started with laissez-faire, and then, they allowed government interventions to a certain degree. Developing countries, though, have started with statism, after the private sector and the market economy expanded over time, the role of the government diminished; meaning that the developing countries also headed for the market economy; however, they cannot be considered implementing the market economy yet. On the other hand, for these developing countries we can safely state that they prioritize the encouragement of the private enterprise and foreign private capital, and they are open to outward-oriented industrialization, and implement a mixed economic regime with a strong private sector.

In the first stages of their development, developing countries used to employ a closed economy and fixed exchange rate system. However, the governments were increasing their expenditures in order to raise the growth rate and to address the social issues; the necessary finances were provided by the central bank which was not independent from the government. This rise in inflation caused by the increase in the volume of money because the exchange rates were fixed was giving rise to an increase in the volume of imports and decrease in the volume of exports, even though they were trying to restrict imports via high rates of customs and import quotas and encourage exports via export incentives. Eventually, the deficits in their balance of payments were forcing these countries to apply to the IMF. On the other hand, the IMF was stipulating devaluation and stability measures, namely, to eliminate their budget deficits, and additionally, instead of public investments, to encourage the private sector and the flow of foreign private capital. The developing country complied with these recommendations in accordance with the stand-by agreement, after a while, was again pursuing the wrong development strategies, and eventually it had to end up applying to the IMF one more time.

From the very outset, as an exception, Hong Kong, Singapore, Taiwan and South Korea succeeded implementing a development strategy based on the open economy, encouragement of private sector and foreign private capital flow and as export-oriented industrialization. Yet, these countries had different traits compared to other developing countries. Hong Kong, for instance, was an international trade center and Singapore was an international finance center they were both city-states. Taiwan and South Korea on the other hand, were appropriate places in terms of political objectives and from the economic point of view, thus, they benefited 
greatly from the flow of intensive American capital. American companies have been importing the goods they manufacturing in Taiwan and South Korea at very low prices. None of the other developing and newly industrializing country, including Turkey, was never subject to such intense foreign capital flow to this extent. Nevertheless, the economic regime implemented in these countries cannot be defined as a pure "market economy" because of the practice of intensive government interventions and protectionism (Toye, 1993).

In the 70s, many development economists draw the attention to the shortcomings of the closed economy implemented generally in the developing countries, and they advocated development strategies based on open economy and export-oriented industrialization (Hiç, 2001 and Toye, 1993).

In fact, many developing countries which were applying the closed economy model were increasing their public investments and consumption expenditures; they could not collect taxes, eventually ending up with high rates inflation. In some Latin American countries the inflation rate reached over $1000 \%$ s. Due to the fixed exchange policy, the demand for imports was increasing while the exports were falling, and despite the IMF's aid, the deficit in the balance of payments was reducing the growth rate for a long time; resulting in an economic frustration in terms of growth and social welfare. Many of governments of developing countries that became aware of the situation tried maintain the same principles even after the stand-by agreements with the IMF throughout the 70s. That means, they tried to minimize the budget deficit and encourage the private sector and foreign capital flow, and they returned to the market exchange rate system by forsaking the fixed exchange rate system. Since the market exchange rate system will enable the balance of payments equilibrium, it facilitated the liberalization of imports. On the other hand, because the existing state economic enterprises were not profitable and productive, privatization programs were carried out within the framework of the IMF's recommendations. Following a series of unsuccessful and inadequate devaluations in the 70s, Turkey, through 24 January austerity measures, has accomplished a very successful economic policy change in this direction (Hiç, 1980, 2008, ps. 8283). After 1983, serious economic measures were taken in many areas including the implementation of open economy, liberalization of imports, adopting market exchange rate regime, providing incentives for foreign private capital (Hiç, 2008, ps. 21-129). The last significant revision was successfully implemented during the 1999 and 2001 economic crises (Hiç, 2008, ps.191-198; and Yeni Türkiye (2001).

\section{Conclusion}

As it was explained before, the economic regime applied in the developing countries cannot be characterized as "market economy". Since the level of development in these countries are lower compared to the developed countries, there need of the level of government interventions, protections and public investments is higher. For this reason, as we mentioned earlier, what is implemented in these countries is not the market economy but a "mixed economy" heading for the market economy which is based on the encouragement of the private sector and foreign private capital. Moreover, democracies of these countries have some difficulties not allowing the market economy to function properly and effectively; and partisanship, nepotism and level of corruption as well as off-the-record sector are much higher than the developed countries. The whole issue here is to have fewer problems in time as the level of education and economic development rises.

In Latin America, though, a limited number of countries such as Venezuela, Argentina and Bolivia have turned into dictatorship and heavy socialist statism because of many failures. These countries make up a very narrow island on the world map.

On the other hand, many countries, including Turkey, have entered the globalization process started in the 90s. China, India and Brazil have taken much advantage from the globalization by conducting pragmatic and successful economic policies, eventually positioning themselves as economically very powerful BRIC (Brazil, Russia, India and China) countries alongside with the developed countries. Despite the negative impact of the 2008 economic crisis, Turkey has recovered very rapidly and today she is among the "emerging markets" group (Hiç, 2010 b). In conclusion, in spite of the 2008 global economic crisis, heading for the market economy and globalization in general will go on in the majority of the developing countries.

\section{References}

- ACKLEY, Gardner (1961) Macroeconomic Theory, Macmillan Co., New York.

- BİROL, Özlen Hiç (2001) Modern Macroeconomic Schools: A Comparison and Evaluation Essay in terms of Consistency and Validity (published doctoral dissertation), Istanbul University, Department of Economics, Istanbul.

- $\quad$ BRANSON, William (1989) Macroeconomic Theory and Policy 2. ed., Prentice-Hall Inc., New Jersey.

- KANYILMAZ, İbrahim (1995) Macroeconomic Theory and Policy (translation of William Branson's book), Alfa, Istanbul.

- KARLUK, Ridvan (2007) The EU and Turkey, 9th Edition, Beta Printing and Distribution Inc., Istanbul. 
- HİÇ, Mükerrem (1974) Capitalism, Socialism, Mixed Economy and Turkey, 2nd Edition, Sermet Printing., Istanbul.

- _ _ _ (1990) "Last Measures Taken. Erroneous Economic Policies Applied Before and Major Problems Faced”, MEBAN Capital Market Bulletin, May, Istanbul.

- _ _ (1994) Monetary Theory and Policy, Filiz Bookstore, Istanbul.

- —_ (2001) "Development Economics from the 50s to our Times", Istanbul University. Journal of Department of Economics, Vol. 51, Issue 2, Fall 2001.

- — _ (2008) A Survey of Turkey's Economy and Politics, Create-Space, Amazon Co.

- — _ (2010) Global Economic Crisis and Turkey, Beykent University, Istanbul.

- _ _ (2010 b) "Major Current Economic and Political Problems Facing Eurasian Countries", Keynote Speech: International Conference on Eurasian Economics 2010, Beykent University.

- $\quad$ PAYA, MERİH (1997) Macroeconomics, Filiz Bookstore, İstanbul.

- TOYE, John (1993) Dilemmas of Development 2. ed., Oxford UK and Cambridge ABD, Blackwell.

- YENI TÜRKIYYE (2001), Special Issue on Economic Crisis, September-October (Issue 41) and NovemberDecember (Issue. 42), Ankara. 